\title{
Mineral and Nutrient Leaf Composition of Two Cassava (Manihot esculenta Crantz) Cultivars Defoliated at Varying Phenological Phases
}

\author{
Oyeyemi Adigun DADA, Oyetola Olusola OWORU \\ Olabisi Onabanjo University, College of Agricultural Sciences, Department of crop production, Yewa \\ Campus, PMB 0012, Ayetoro,Ogun state, Nigeria; oadada247@yahoo.com
}

\begin{abstract}
The effect of defoliation on mineral and food value of two cassava varieties defoliated at varying phenological phases was studied to ascertain the appropriate phenological phase when harvested leaves would contain the optimum mineral and proximate composition, gross energy and the least cyanide content. Two cassava cultivars were subjected to defoliation at varying phenological stages including logarithmic, vegetative and physiological maturity phases. The mineral content was highest at the logarithmic phase than any other phases. The proximate composition of the cassava leaves showed that crude protein was highest at physiological maturity, while the least $\mathrm{HCN}$ was observed in cassava defoliated at logarithmic phase. Analysis of mineral and proximate content showed that leaf of the 'TMS30572' cultivar had the highest mineral content, fat, fibre, ash, dry matter and gross energy at the logarithm phase while 'OkoIyawo' had the highest crude protein and HCN at physiological maturity. This study indicates the high potential of cassava leaf as an unconventional source of protein for both humans and animals when defoliated at logarithmic growth phase.
\end{abstract}

Keywords: cassava, defoliation, phenological stage, proximate composition, hydrocyanide

\section{Introduction}

Tender leaves of cassava which could be harvested periodically throughout the growing season are utilized in some areas as relish, particularly during the dry season, when there are few leafy vegetables (IITA, 1990). In addition, leaf meal could also be prepared from cassava leaves as a component of livestock feed (Fasuyi, 2005). Leaf harvesting involves plucking the fully expanded tender leaves and the same field can be visited frequently if it is the only available cassava field.

Nutritionally, the cassava leaf is rich in protein (14$40 \%$ ), potassium, iron, calcium, sodium, vitamin B1, B2, B6, C and carotenes (Eggum, 1970; Adewusi and Bradbury, 1993; Bokanga, 1994). It has been reported that apart from lower methionine, lysine, and perhaps isoleucine content, the amino acid profile of cassava leaf proteins compares favorably with those of milk, cheese, soybean, fish, egg (Ravindran, 1990; Wanapat, 2001). Nonetheless, exploitation of the food value of this crop is greatly masked by the endogenous presence of cyanogenic glucosides. These glucosides, typified by linamarin [2-( $\alpha-$ Dglucopyranosyloxy) isobutyronitrile] and lotaustralin [2- ( $\alpha$ - D glucopyranosyloxy) methylbutyronitrile] are hydrolyzed to hydrocyanic acid (HCN) by endogenous linamarase (EC. 3.1.1.21, linamarin, $\alpha$-D-glucoside glucohydrolase) when cassava tissues are disrupted by cutting, grating, bruising or other mechanical means (Conn, 1969; Bradbury et al., 1991).

Cassava leaves are normally harvested indiscriminately for their nutritional potential for both livestock and hu- man consumption. Nevertheless, the effect of defoliation on the overall performance of cassava plants is not known. According to Salisbury and Ross (2004), the response of plants to defoliation depends on the intensity or extent, frequency and timing of foliage removal. Defoliation of plants may affect the photosynthate reserves, canopy development and root yield of cassava (Oworu et al., 2008). It is likely that defoliation will not have deleterious influence on the quantity and quality of mineral and nutrient composition of cassava leaf since the leaf is the main source where photosynthates are partitioned into sinks (Subedi and Ma, 2005). It is not clear therefore, if defoliation at a certain phenological stage would negatively affect the quality of the mineral and nutrient composition of cassava crop. Thus, it is pertinent from the foregoing, that the research effort must be channeled towards ascertaining the critical phenological stage when the optimum quantity of minerals and food constituents could be obtained in other to harness the nutritional potentials of cassava leaves in both human and livestock diets.

A better understanding of the relationship between defoliation and quantity of mineral and nutrient component of cassava leaf would help to improve our ability to predict the quality of cassava leaf meal when the crop is defoliated at varying phenological growth phases. This study provides analytical information on the mineral content, proximate composition, hydrogen cyanide and metabolizable energy values of cassava leaf of commonly grown local and improved cultivar defoliated at varying phenological growth phases in derived savanna agro-ecology. 


\section{Materials and methods}

The study was conducted at the teaching and research farm of the College of Agricultural Sciences, Olabisi Onabanjo University, Yewa campus, Ayetoro. The study area was located at an latitude of $7^{\circ} 12^{\prime}$ and longitude of $30^{\circ} 0^{\prime}$. It has a climatic feature typical of a derived savanna area with a mean annual rainfall of $1,250 \mathrm{~mm}$ and mean temperature of $26^{\circ} \mathrm{C}$. The experimental site has been left fallowed for six years. The land was prepared by slash and burn method after which the land was ploughed and harrowed. The experimental design was split-plot fitted into a randomized complete block. The main plot effect involved two varieties of cassava-'TMS30572' (improved variety) and 'Oko-Iyawo' (local variety), the sub-plot effect was defoliation at three growth stages (logarithmic, vegetative and physiological maturity). The factorial combination gave six treatments. The two cultivars were planted during 2007 and 2008 planting seasons on prepared land following the experimental layout. The crop was cultivated at a planting distance of $0.9 \mathrm{M} \times 0.9 \mathrm{M}$ to give a planting population of 12,346 plant/ha. Regular cultural practices were carried out on the plot such as weed, pest and diseases management as recommended for the crop but no fertilizer was applied.

\section{Data collection}

Data were collected every three months representing the phenological stages (logarithmic, vegetative and physiological maturity) from two plants tagged at the center row of the sampled plots. Data were collected on the weight of fresh and dry leaves. Harvested leaves were oven dried at $80^{\circ} \mathrm{C}$ for 48 hours to determine the leaf dry matter yield for further proximate/mineral composition analysis.

\section{Proximate/mineral composition and gross energy}

The proximate constituents of the air-dried materials were determined after AOAC, (1998). All analyses were carried out in duplicate. The $\mathrm{Na}$ and $\mathrm{K}$ content were determined by flame photometry and $\mathrm{P}$ was determined by the vanado-molybdate method (Bray and Kurtz, 1945). The other mineral elements were determined after wet digestion with a mixture of nitric acid, sulphuric and hydrochloric acid using Atomic Absorption Spectrophotometer (AAS Model SP9). Gross energy of the dry material was determined against thermocouple grade benzoic acid using a Gallenkamp ballistic bomb calorimeter (Model CBB -330-0104L).

\section{Determination of hydrocyanic acid}

The cyanide potential of the harvested leaves was determined (after an initial extraction for 2-4 minutes of 6-10 g material in $0.1 \mathrm{ml} \mathrm{H}_{3} \mathrm{PO}_{4}$ by a $2 \mathrm{ml} \mathrm{H}_{2} \mathrm{SO}_{4}\left(100^{\circ} \mathrm{C}\right.$ for 50 $\mathrm{min}$ ) hydrolysis followed by reaction with chloramines- $\mathrm{T}$ pyridine barbituric acid (Konig reaction) as developed by Bradbury et al. (1991). KCN dried over concentrated
$\mathrm{H}_{2} \mathrm{SO}_{4}$ was used to calibrate the standard curve from a stock solution containing $75 \mathrm{mg} \mathrm{KCN} / 100 \mathrm{ml}$.

\section{Statistical analysis}

Data collected were subjected to analysis of variance (ANOVA) using the general linear model procedure (PROCGLM) of Statistical Analysis System (SAS, 1999). Means were separated using Duncan multiple range test (DMRT) at 5\%.

\section{Result and discussion}

Defoliation of cassava plants at different phenological phases significantly $(\mathrm{P} \leq 0.05)$ affected the fresh and dry leaf yield of the crop. Defoliation at the vegetative phase seems to support the growth, especially mean fresh and dry leaf yield per plant (Tab. 1).

Tab. 1. Influence of defoliation on fresh and dry leaf yield of cassava defoliated at different phenological phases

\begin{tabular}{ccc}
\hline Phenological phase & $\begin{array}{c}\text { Weight of fresh } \\
\text { leaves }(\mathrm{g}) / \text { plant }\end{array}$ & $\begin{array}{c}\text { Weight of dry } \\
\text { leaves }(\mathrm{g}) / \text { plant }\end{array}$ \\
\hline Logarithmic & $30.45 \mathrm{~b}$ & $17.97 \mathrm{~b}$ \\
Vegetative & $98.67 \mathrm{a}$ & $55.90 \mathrm{a}$ \\
Physiological maturity & $20.03 \mathrm{c}$ & $13.30 \mathrm{c}$ \\
\hline
\end{tabular}

Means with similar alphabets along the column are not significantly different $\mathrm{P} \leq 0.05$ (DMRT)

The growth response of the two cultivars revealed that 'Oko-Iyawo', a late maturing cultivar displayed a significantly better response to defoliation than 'TMS30572' an early maturing cultivar in the study area. The weight of the fresh $(59.92 \mathrm{~g})$ and dry leaves $(35.50 \mathrm{~g})$ obtained from 'Oko-Iyawo' was significantly better than that observed in 'TMS30572' (Tab. 2).

Tab. 2. Influence of defoliation on fresh and dry leaf yield of two cassava varieties defoliated at different phenological phases

\begin{tabular}{ccc}
\hline Cultivars & $\begin{array}{c}\text { Fresh leaves } \\
(\mathrm{g}) / \text { plant }\end{array}$ & $\begin{array}{c}\text { Weight of dry leaves } \\
(\mathrm{g}) / \text { plant }\end{array}$ \\
\hline 'Oko-Iyawo' & $59.52 \mathrm{a}$ & $35.50 \mathrm{a}$ \\
'TMS30572' & $39.92 \mathrm{~b}$ & $22.62 \mathrm{~b}$ \\
\hline
\end{tabular}

The mineral composition of the cassava leaf defoliated at varying phenological phase is presented in Tab. 3 . The result indicated that the amount of $\mathrm{Na}, \mathrm{K}, \mathrm{Ca}$ and $\mathrm{P}$ composition of the cassava leaf decreased with an increase in the age of the crop with a mean value of $0.10,0.32$, $0.37,0.94$, and $147.67 \%$ respectively. Similarly, most $\mathrm{Mn}$ $(0.23 \mathrm{mg} / \mathrm{l}), \mathrm{Fe}(0.200 \mathrm{mg} / \mathrm{l})$ and $\mathrm{Cu}(0.003 \mathrm{mg} / \mathrm{l})$ were synthesized at the vegetative growth stage. The result showed that the amount of the phosphorus (1.08\%), potassium $(0.47 \%)$ constituent of defoliated leaves was highest at the logarithm stage of growth, while the amount of calcium $(0.47 \%)$ was higher at the vegetative growth phase than any other growth phase. 
Tab. 3. Influence of defoliation at varying phenological phase on mineral composition of cassava leaf

\begin{tabular}{cccccccccc}
\hline Growth stages & $\mathrm{Na}(\%)$ & $\mathrm{K}(\%)$ & $\mathrm{Ca}(\%)$ & $\mathrm{Mg}(\%)$ & $\mathrm{P}(\%)$ & $\mathrm{Mn}(\mathrm{mg} / \mathrm{l})$ & $\mathrm{Zn}(\mathrm{mg} / \mathrm{l})$ & $\mathrm{Fe}(\mathrm{mg} / \mathrm{l})$ & $\mathrm{Cu}(\mathrm{mg} / \mathrm{l})$ \\
\hline Logarithmic & 0.13 & 0.47 & 0.33 & 0.04 & 1.08 & 0.200 & 0.004 & 0.170 & 0.002 \\
Vegetative & 0.10 & 0.31 & 0.47 & 0.04 & 0.88 & 0.230 & 0.004 & 0.200 & 0.003 \\
Physiological maturity & 0.09 & 0.18 & 0.31 & 0.04 & 0.86 & 0.210 & 0.003 & 0.180 & 0.001 \\
Mean & 0.10 & 0.32 & 0.37 & 0.04 & 0.94 & 0.212 & 0.004 & 0.181 & 0.002 \\
SD \pm & 0.02 & 0.14 & 0.09 & 0.01 & 0.12 & 0.009 & 0.001 & 0.001 & 0.001 \\
Coefficient of variation (\%) & 19.56 & 44.82 & 23.32 & 7.53 & 13.01 & 7.072 & 13.650 & 7.479 & 40.894 \\
\hline
\end{tabular}

The phenological stages differed distinctly in $\mathrm{K}, \mathrm{Ca}$ and $\mathrm{Cu}$ as shown by the high $\mathrm{CV}$ of $44.82 \%, 23.32 \%$ and $40.89 \%$ respectively. This implies that leaves harvested at the early stage of cassava growth, contained more of the minerals than those harvested at the latter age. This infers that harvesting of cassava leaf at root harvest or physiological maturity may reduce beneficial effect on the consumers be it humans or livestock as the least amount of mineral elements were obtained at this phase.This suggests that absolute nutrient potential derivable from the leaf of the crop may not be fully exploited at the maturity phase. This may not be unconnected to the fact that some of the nutrient uptake by the crop would have to be partitioned into other sinks for optimal metabolic processes of the crop. Ekanayake (1996) reported that cassava has two growth patterns, namely the developmental phase involving root bulking takes the major share of the assimilates. The root bulking stage corresponds to the post vegetative stage when assimilates are translocated into the storage root (Ravindran and Rajaguru, 1988). This study therefore suggests that leaf harvesting could be done at the logarithmic or vegetative growth stages, where the highest percent of most of the mineral was synthesized and partitioned.

The mineral composition of the two cassava varieties is presented in Tab. 4. 'TMS30572' showed superior performance in terms of mineral constituents except for
Mn where 'Oko-Iyawo' had the highest $(0.435 \mathrm{mg} / \mathrm{l})$ composition. The findings agree with the report of Ravindran and Rajaguru (1988) that genetic variability exists among cultivars, which is reflected in their differences in mineral composition as shown in the case of the two cultivars used for this study.

\section{Interactions}

In both cassava cultivars, the mineral content found in the leaves was more at the logarithm phase than any other phases of cassava growth except for $\mathrm{Ca}, \mathrm{Mn}$ and Fe which were higher at the vegetative phase. This suggests that in cassava, the quality of mineral nutrient available varies with age and variety. Hence, cassava growers could synchronize leaf harvesting to a particular phenological stage when the desired mineral nutrient is optimum. In this study, $\mathrm{Ca}, \mathrm{Mn}$, $\mathrm{Fe}$ and $\mathrm{Cu}$ were highest in both cultivars at the vegetative growth phase and least at the physiological maturity (Tab. $5)$. This finding agrees with the report of Ravindran and Rajaguru (1988) and Dixon et al. (2002) who reported that stage of maturity, cultivar effects, abiotic and biotic constraints are the major factors contributing to variability in mineral nutrient content of crops.

Tab. 6 showed the proximate composition of cassava leaves defoliated at varying phenological stages. The results showed that cassava leaf possess adequate nutrient

Tab. 4. Varietal influence on mineral composition of cassava defoliated at varying phenological phases

\begin{tabular}{ccccccccccc}
\hline Varieties & $\mathrm{Na}(\%)$ & $\mathrm{K}(\%)$ & $\mathrm{Ca}(\%)$ & $\mathrm{Mg}(\%)$ & $\mathrm{P}(\%)$ & $\mathrm{Mn}(\mathrm{mg} / \mathrm{l})$ & $\mathrm{Zn}(\mathrm{mg} / \mathrm{l})$ & $\mathrm{Fe}(\mathrm{mg} / \mathrm{l})$ & $\mathrm{Cu}(\mathrm{mg} / \mathrm{l})$ \\
\hline 'TMS30572' & 0.22 & 0.67 & 0.68 & 0.09 & 1.99 & 0.404 & 0.008 & 0.368 & 0.004 \\
'Oko-Iyawo' & 0.20 & 0.62 & 0.76 & 0.07 & 1.81 & 0.435 & 0.008 & 0.350 & 0.004 \\
Mean & 0.21 & 0.65 & 0.72 & 0.08 & 1.91 & 0.419 & 0.008 & 0.359 & 0.004 \\
$\mathrm{SD} \pm$ & 0.01 & 0.04 & 0.06 & 0.01 & 0.13 & 0.022 & 0.003 & 0.013 & 0.004 \\
Coefficient of variation (\%) & 6.73 & 5.48 & 7.86 & 17.70 & 6.70 & 5.330 & 3.580 & 3.550 & 12.220 \\
\hline
\end{tabular}

Tab. 5. Mineral composition of two cassava varieties defoliated at different phenological stages

\begin{tabular}{|c|c|c|c|c|c|c|c|c|c|c|c|c|c|c|c|c|c|c|}
\hline \multirow{2}{*}{$\begin{array}{l}\text { Growth } \\
\text { stages }\end{array}$} & \multicolumn{2}{|c|}{$\mathrm{Na}(\%)$} & \multicolumn{2}{|c|}{$\mathrm{K}(\%)$} & \multicolumn{2}{|c|}{$\mathrm{Ca}(\%)$} & \multicolumn{2}{|c|}{$\operatorname{Mg}(\%)$} & \multicolumn{2}{|c|}{$\mathrm{P}(\%)$} & \multicolumn{2}{|c|}{$\mathrm{Mn}(\mathrm{mg} / \mathrm{l})$} & \multicolumn{2}{|c|}{$\mathrm{Zn}(\mathrm{mg} / \mathrm{l})$} & \multicolumn{2}{|c|}{$\mathrm{Fe}(\mathrm{mg} / \mathrm{l})$} & \multicolumn{2}{|c|}{$\mathrm{Cu}(\mathrm{mg} / \mathrm{l})$} \\
\hline & $\mathrm{V} 1$ & $\mathrm{~V} 2$ & V1 & $\mathrm{V} 2$ & V1 & $\mathrm{V} 2$ & $\mathrm{~V} 1$ & $\mathrm{~V} 2$ & V1 & $\mathrm{V} 2$ & V1 & $\mathrm{V} 2$ & V1 & $\mathrm{V} 2$ & V1 & $\mathrm{V} 2$ & V1 & $\mathrm{V} 2$ \\
\hline Vegetative & 0.07 & 0.06 & 0.22 & 0.18 & 0.33 & 0.27 & 0.02 & 0.04 & 0.59 & 0.57 & 0.158 & 0.141 & 0.003 & 0.003 & 0.132 & 0.129 & 0.002 & 0.001 \\
\hline $\begin{array}{c}\text { Physiological } \\
\text { maturity }\end{array}$ & 0.05 & 0.07 & 0.11 & 0.14 & 0.23 & 0.16 & 0.03 & 0.02 & 0.54 & 0.63 & 0.146 & 0.125 & 0.002 & 0.002 & 0.123 & 0.104 & 0.001 & 0.001 \\
\hline Mean & 0.07 & 0.07 & 0.21 & 0.22 & 0.25 & 0.23 & 0.02 & 0.03 & 0.06 & 0.66 & 0.290 & 0.269 & 0.005 & 0.005 & 0.245 & 0.233 & 0.003 & 0.002 \\
\hline $\mathrm{SD} \pm$ & 0.02 & 0.02 & 0.09 & 0.11 & 0.07 & 0.06 & 0.01 & 0.01 & 0.07 & 0.11 & 0.014 & 0.009 & 0.004 & 0.004 & 0.010 & 0.013 & 0.007 & 0.006 \\
\hline $\begin{array}{c}\text { Coeff. of } \\
\text { variation (\%) }\end{array}$ & 22.91 & 20.83 & 43.91 & 49.93 & 26.87 & 25.85 & 24.74 & 33.33 & 11.76 & 17.14 & 4.670 & 3.270 & 8.110 & 6.680 & 3.870 & 5.359 & 22.690 & 23.050 \\
\hline
\end{tabular}

V1= 'Oko-Iyawo', V2 = 'TMS30572', SD= Standard deviation 
such as crude protein, fat, fibre, ash, that can supply gross energy needed by humans and livestock for healthy living as reported by Ravindran and Rajaguru (1988) and WHO (1996). This result also revealed that the percentage of fat, fibre, and ash content of the leaves is inversely proportional to the age of the crop. This presumes that tender leaves of cassava seem to possess more food component than older ones. It was also observed that the proximate composition of leaves defoliated at vegetative phases appears optimum except for the hydrocyanide content which was highest $(59.72 \mathrm{mg} / \mathrm{kg})$ at this phase. Consequently, defoliation could be encouraged at the vegetative stage rather than at the root harvest should the leaves be processed for humans and livestock composition. Crude protein and hydrogen cyanide content of the crop increased with age of the crop reaching their peak at vegetative phase $(59.72 \mathrm{mg} / \mathrm{kg})$. This suggests that leaf harvesting at vegetative phase must be subjected to appropriate treatment to minimize cyanide poisoning associated with consumption of cassava leaves as suggested by Aletor and Adeogun (1995) and Fasuyi (2005).

The results in Tab. 7 showed the variation in the proximate composition of two cassava varieties. The results of the proximate analysis showed that leaves from the 'OkoIyawo' cultivar were high in crude protein $(71.71 \%)$, ash
(23.57\%) and hydrogen cyanide $(85.6 \mathrm{Mg} / \mathrm{kg})$. Leaves harvested from 'TMS30572' were low in crude protein (69.60\%), fat (20.50\%), ash (22.14\%) and hydrogen cyanide $(82.30 \mathrm{mg} / \mathrm{kg})$. The gross energy component of 'TMS30572' was higher $(8.44 \mathrm{Kcal} / \mathrm{g})$ than that found in 'Oko-Iyawo' $(8.31 \mathrm{Kcal} / \mathrm{g})$ with CV of $1.10 \%$. The result suggests that cassava cultivars differ in their nutrient composition irrespective of the defoliation periods. In this study, 'Oko-Iyawo' seems to perform better in terms of protein $(71.71 \%, \mathrm{CV}$ of $2.03 \%)$ and fibre $(49.80 \%$ and CV of $0.64 \%$ ) composition nonetheless the hydrogen cyanide scare associated with the utilization of cassava leaf for both human and livestock feed was high in this cultivar $(85.60 \mathrm{Mg} / \mathrm{kg}$ and $\mathrm{CV}$ of $2.76 \%)$. Although the $\mathrm{HCN}$ content in 'Oko-Iyawo' appeared to be high, it is still within the range that can be broken down during processing as proposed by Fasuyi, 2005. Leaves harvested from the 'Oko-Iyawo' cultivar seemed adequate for ruminants and monogastric livestock, as well as humans considering the nutrient composition.

The response of the two cassava cultivars to defoliation at varying phenological (Tab. 8) phases showed that the two cultivars responded differently in terms of proximate composition of the food and hydrogen-cyanide contents. The results showed that the 'Oko-Iyawo' cul-

Tab. 6. Proximate composition gross energy value and hydrogencyanide of cassava plants defoliated at varying phenological stages

\begin{tabular}{cccccccc}
\hline Growth stages & $\begin{array}{c}\text { Crude protein } \\
(\%)\end{array}$ & $\begin{array}{c}\text { Fat } \\
(\%)\end{array}$ & $\begin{array}{c}\text { Fibre } \\
(\%)\end{array}$ & $\begin{array}{c}\text { Ash } \\
(\%)\end{array}$ & $\begin{array}{c}\text { Dry matter } \\
(\%)\end{array}$ & $\begin{array}{c}\text { Gross energy } \\
\mathrm{Kcal} / \mathrm{g}\end{array}$ & $\begin{array}{c}\text { Hydrogen cyanide } \\
\mathrm{Mg} / \mathrm{kg}\end{array}$ \\
\hline Logarithmic & 45.45 & 14.12 & 35.24 & 14.93 & 174.32 & 5.79 & 49.58 \\
Vegetative & 47.40 & 13.77 & 33.52 & 16.42 & 173.99 & 5.52 & 59.72 \\
Physiological maturity & 48.58 & 13.00 & 31.66 & 14.36 & 173.34 & 5.44 & 58.60 \\
Mean & 47.13 & 13.60 & 33.50 & 15.24 & 173.90 & 5.58 & 56.00 \\
SD \pm & 1.56 & 0.57 & 1.79 & 1.06 & 0.50 & 0.18 & 5.56 \\
\hline Coefficient of variation (\%) & 3.32 & 4.20 & 5.35 & 6.98 & 0.29 & 3.28 & 9.93 \\
\hline
\end{tabular}

Tab. 7. Proximate composition, gross energy values, hydrogen cyanide of two defoliated cassava varieties

\begin{tabular}{cccccccc}
\hline Variety & $\begin{array}{c}\text { Crude protein } \\
(\%)\end{array}$ & $\begin{array}{c}\text { Fat } \\
(\%)\end{array}$ & $\begin{array}{c}\text { Fibre } \\
(\%)\end{array}$ & Ash $(\%)$ & $\begin{array}{c}\text { Dry matter } \\
(\%)\end{array}$ & $\begin{array}{c}\text { Gross energy } \\
(\mathrm{Kcal} / \mathrm{g})\end{array}$ & $\begin{array}{c}\text { Hydrogen cyanide } \\
(\mathrm{Mg} / \mathrm{kg})\end{array}$ \\
\hline 'Oko-Iyawo' & 71.71 & 20.40 & 49.80 & 23.57 & 260.60 & 8.31 & 85.60 \\
'TMS30572' & 69.68 & 20.50 & 50.70 & 22.16 & 261.00 & 8.44 & 82.30 \\
Mean & 70.70 & 20.40 & 50.20 & 22.86 & 260.80 & 8.38 & 84.00 \\
SD \pm & 1.44 & 0.13 & 0.64 & 1.01 & 0.29 & 0.09 & 2.32 \\
Coefficient of Variation (\%) & 2.03 & 0.66 & 1.27 & 4.42 & 0.11 & 1.10 & 2.76 \\
\hline
\end{tabular}

Tab. 8. Proximate composition, gross values, hydrogen cyanide, of two cassava leaves defoliated at varying phenological stages

\begin{tabular}{|c|c|c|c|c|c|c|c|c|c|c|c|c|c|c|}
\hline \multirow[t]{2}{*}{ Growth stages } & \multicolumn{2}{|c|}{$\begin{array}{c}\text { Crude protein } \\
(\%)\end{array}$} & \multicolumn{2}{|c|}{$\begin{array}{l}\text { Fat } \\
(\%)\end{array}$} & \multicolumn{2}{|c|}{$\begin{array}{c}\text { Fibre } \\
(\%)\end{array}$} & \multicolumn{2}{|c|}{$\begin{array}{l}\text { Ash } \\
(\%)\end{array}$} & \multicolumn{2}{|c|}{$\begin{array}{c}\text { Dry matter } \\
(\%)\end{array}$} & \multicolumn{2}{|c|}{$\begin{array}{c}\text { Gross energy } \\
(\mathrm{kcal} / \mathrm{g})\end{array}$} & \multicolumn{2}{|c|}{$\begin{array}{c}\text { Hydrogen cyanide } \\
(\mathrm{Mg} / \mathrm{kg})\end{array}$} \\
\hline & $\mathrm{V} 1$ & $\mathrm{~V} 2$ & V1 & $\mathrm{V} 2$ & $\mathrm{~V} 1$ & $\mathrm{~V} 2$ & V1 & $\mathrm{V} 2$ & V1 & $\mathrm{V} 2$ & $\mathrm{~V} 1$ & $\mathrm{~V} 2$ & $\mathrm{~V} 1$ & $\mathrm{~V} 2$ \\
\hline Logarithmic & 24.16 & 21.29 & 6.69 & 7.43 & 16.79 & 18.45 & 7.26 & 7.67 & 86.89 & 87.43 & 2.82 & 2.97 & 25.26 & 24.32 \\
\hline Vegetative & 22.66 & 24.74 & 7.24 & 6.53 & 17.54 & & 9.29 & 7.13 & 87.15 & & & 2.71 & 29.25 & \\
\hline Physiological maturity & 24.89 & 23.65 & 6.42 & 6.58 & 15.43 & 16.23 & 7.02 & 7.34 & 86.58 & 86.76 & 2.68 & 2.76 & 31.08 & 27.52 \\
\hline Mean & 23.90 & 23.23 & 6.78 & 6.85 & 16.59 & 16.89 & 7.86 & 7.38 & 86.87 & 87.01 & 2.77 & 2.81 & 28.53 & 27.44 \\
\hline $\mathrm{SD} \pm$ & 1.14 & 1.76 & 0.42 & 0.51 & 1.07 & 1.36 & 1.25 & 0.27 & 0.29 & 0.37 & 0.08 & 0.14 & 2.98 & 3.08 \\
\hline Coefficient of variation (\%) & 4.76 & 7.59 & 6.16 & 7.39 & 6.45 & 8.05 & 15.87 & 3.69 & 0.33 & 0.42 & 2.82 & 4.90 & 10.43 & 11.21 \\
\hline
\end{tabular}

V1 = 'Oko-Iyawo', V2 = 'TMS30572' 
48

tivar had higher crude protein (24.89\%) and hydrogen cyanide $(31.08 \%)$ content at physiological maturity. On the contrary, 'TMS30572' crude protein and hydrogen cyanide reached their maximum $(24.74 \%, 30.47 \mathrm{mg} / \mathrm{kg})$ respectively at the vegetative phase. More fat (7.24\%) and fibre $(17.54 \%)$ and dry matter $(87.15 \%)$ were synthesized respectively at the vegetative phase in 'Oko-Iyawo'. Also, similar food component such as fat $(7.43 \%)$, fibre $(18.45 \%)$, dry matter $(87.43 \%)$ were more at logarithm growth phase in 'TMS30372'. Both cultivars had more gross energy; $2.82 \mathrm{Kcal} / \mathrm{g}$ ('Oko-Iyawo') and $2.97 \mathrm{Kcal} / \mathrm{g}$ ('TMS30572') at the logarithmic phase.

\section{Conclusions}

Defoliation significantly affects the quality and quantity of mineral and food component of cassava cultivars. However, different cultivars respond differently to defoliation at different stages of growth. Defoliation of cassava cultivars at vegetative growth stage seems appropriate in order to take full advantage of mineral nutrient and food value of cassava leaf when harvested for human consumption as vegetable or in leaf meal for livestock. Also, in the study area 'Oko-Iyawo' cultivar tolerated defoliation better than 'TMS30572' in terms of leaf yield, mineral nutrient contents. However, 'TMS30572' had the lowest hydrogencyanide potential and was high in gross energy and dry matter composition with appreciable protein content at logarithmic phase that can conveniently replace the conventional protein sources. In addition, the cyanide potentials in the leaves could be gotten rid off through processing as prescribed by Fasuyi, 2005, as he suggested a combination of shredding and sun drying to be the most effective technique of reducing cyanide content of cassava leaves and could be used for either livestock or human consumption.

This study indicates the high potential of cassava leaf for 'TMS30572' as an unconventional source of protein and other minerals with lowest cyanide potentials for both humans and livestock when defoliated at the logarithmic growth phase. The fat content, which is involved as a useful matter which can provide aid to the easy movement of gastrointestinal tract during digestion. The cassava leaf is a veritable replacement for conventional protein sources which are presently expensive and in high completion with human consumption. The potential leaf yield, mineral nutrient and food component of cassava leaves varied considerable depending on the cultivar, frequency of harvest and age of plant.

\section{References}

Aletor, V. A. and O. A. Adeogun (1995). Nutrient and antinutrients components of some tropical leafy vegetables. Food Chem. J. 53:375-379.
A.O.A.C (1998). Association of Official Analytical Chemist. Official method of analysis, Washington D.C., U.S.A.

Adewusi, S. R. A and J. H. Bradbury (1993). Carotenoids in cassava; comparison of open column and HPLC methods of analysis. J. Sci. Food. Agri. 62:375-383.

Bokanga, M. (1994). Processing of cassava leaves for human consumption. Acta Hort. 375:203-207.

Bradbury, J. H., S. M. Egan and M. J. Lynch (1991). Analysis of cyanide in cassava using acid hydrolysis of cyanogenic glucosides. J. Sci. Food Agri. 55:277-290.

Bray, R. H and L. T. Kurtz (1945). Determination of total organic and available forms of phosphorus in soils. Soil Sci. 59:39-45.

Conn, E. E. (1969). Cyanogenic glycosides. J. Food Chem. 17:519-526.

Ekanayake, I. J. (1996). Cassavana Procedures for Growth Analysis. A procedures manual of crop i,provement divisionof IITA.

Eggum, R. O. (1970). The protein quality of cassava leaves. Br. J. Nutr. 24:761-768.

Fasuyi, A.O.(2005). Nutrient composition and processing effects oncassava leaf (Manihot esculenta, crantz) antinutrients. Pak. J. Nutr. 4(1):37-42

International Institute of Tropical Agriculture-IITA (1990). Cassava in tropical Africa. A reference manual. IITA. Ibadan, Nigeria.

Oworu, O. O., O. A. Dada, R. Ndubuaku and O. O. Opebi (2008). Canopy development and root yield of cassava influenced by intensity and time of defoliation. In: O. A. Fagade (Eds.). Bull. of the Sci Association of Nigeria. $44^{\text {th }}$ Annual Conference held at University of Ibadan. (In press).

Ravindran, V. (1990). Preparation of cassava leaf products and their use as animal feeds, 81-95 pp. Proceeding of the FAO expert consultation, CIAT, Cali, Columbia 21-25 January 1991.

Ravindran, V. and H. Rajaguru (1988). Effect of stem pruning on cassava root yield and leaf yield. Srilankan Journal of Agricultural Sciences 25(2):32-37.

SAS (1999). Statistical Analysis System Users manual guide N/ Carolina.

Salisbury, F. B. and C. W. Ross (2004). Plant physiology. CBS Pub. And Distribution, N/Delhi, India pp.299-309.

Subedi, K. D. and B. L. Ma (2005). Nitrogen uptake and partitioning in stay- green and leafy maize hybrids. Crop Science 45:740-747.

Wanapat, M. (2001). Role of cassava as animal feed in the tropics, 225-226 pp. In: Preston, T. R., B. Ogle and M. Wanapat (Eds.). Proceedings of International Workshop on Current Research and Development use of cassava as animal feed. Stockholm, SIDA-SAREC. 